Journal of World Englishes and Educational Practices (JWEEP)

ISSN: 2707-7586

DOI: $10.32996 /$ jweep

Website: https://al-kindipublisher.com/index.php/jweep/index

\title{
Research Capability of Teachers: Its Correlates, Determinants and Implications for Continuing Professional Development
}

Manuel E. Caingcoy

Bukidnon State University, Philippines

Corresponding Author: Manuel E. Caingcoy, Email: caingcoymanuel@gmail.com, manuelcaingcoy@buksu.edu.ph

\section{ARTICLE INFO}

Received: September 21, 2020

Accepted: October 10, 2020

Volume: 2

Issue: 5

DOI: 10.32996/jweep.2020.2.5.1

\section{KEYWORDS}

Attitudes, motivation, mentoring skills, action planning skills, years of service, research processes, age, research productivity

\section{ABSTRACT}

Recently, research capability has received an overwhelming and remarkable interest among academics and practitioners. This is timely since the Department of Education had institutionalized research and encouraged teachers to engage in it to support evidence-based practice, decision-making, policy, and program development. On these premises, a study was carried out to assess the research capability of public teachers in Malaybalay City, determine its correlates and determinants. It utilized descriptive, correlational, and explanatory designs. It administered survey questionnaires to 92 participants. Data were analyzed using descriptive and inferential statistics. The results revealed that teachers were slightly capable of conducting research and having neutral attitudes toward it, motivated to write research, had a high level of difficulties in research processes, and moderately capable of action planning. They also show evidence of potential in mentoring. Further, mentoring and action planning skills, motivation to write research, attitudes toward research, and the number of studies completed by teachers were the correlates of their research capability at different magnitudes of the relationship. Notably, the research capability of teachers had a low, negative but significant relationship with their age and accumulated years of service. Thus, this capability deteriorates as they age and accumulate years of service. The motivation to write research, the number of studies completed, and age were the determinants of research capability. It was concluded that research capability can be determined and predicted by how motivated teachers are to write research, how productive they are in research, and how young they are when they engage in this rigorous endeavor. The study identified and recommended topics for continuing professional development.

\section{Introduction}

Lately, research capability has received an overwhelming and remarkable interest from numerous academics in tourism and hospitality management (Abarquez et al., 2013), nursing (Li et al., 2019), dentistry (Manongsong et al.,2018), business entrepreneurship and accountancy (Narag, et al., 2016), maritime (Formeloza et al., 2013), higher education in general (Salom, 2013; De la Cruz, 2016; Kho et al., 2017; Salem et al., 2016; Enero et al., 2017), and basic education (Pati, 2014; Abarro et al., 2016; Wong, 2019; Ulla et al., 2017; Udompong et al., 2014). This indicates that there are more experts and professionals now than before who recognized its significance in improving practice. Henceforth, its importance is beyond determining what one knows and can do in research.

\section{K C AL-KINDI CENTER R D FOR RESEARCH AND} Your gateway to world-class research
Published by Al-KindiCenter for Research and Development. Copyright (c) the author(s). This is an open access article under CC BY license (https://creativecommons.org/licenses/by/4.0/) 
Research capability refers to one's facility to undertake high-quality studies (Salom, 2013). Ismail et al. (2012) theorized it as an "ability to carry out data collection involving planning and selecting appropriate data collection tools or instruments, identifying an appropriate method for interpreting and manipulating data and applying an appropriate statistical tool for [the] test of significance besides understanding" (p. 245). Such capability may develop over time, through experience (Manongsong et al., 2018) continuing and relevant capacity-building activities. Also, it requires a consistent application of the acquired knowledge and skills to produce research output and innovation. Advancing it takes a lot of consideration in individuals like their motivation to get involved in it, the attitudes toward it, and other skills necessary for undertaking the systematic and tedious process of research.

As a construct, research capability may connote differently as actions, activities or series of training conducted to capacitate aspiring or seasoned researchers (Mani et al., 2010). On the other hand, it may indicate otherwise as skill, ability, literacy or competency to conduct research. The latter is the outcome of the former, which is the process of acquiring knowledge, skills, attitudes, scientific literacy, capacity, and competency in conducting research. Holt et al. (2011) conjectured that there has been confusion between these terms, competency, or capability. To compare, "capability describes the ability of an organization or unit. Competence describes the ability of an individual to do something" (Holt et al., 2011, p. 5). Even so, it was admitted that these terms have inherently very close to each other. This is why studies tend to use them interchangeably. In a causal model, scientific literacy and research competency were taken separately (Udompong et al., 2014).

There have been numerous studies on research capability (Abarro et al., 2016; Abarquez et al., 2013; Basilio et al., 2019; De la Cruz, 2016; Formeloza et al., 2013; Gomez et al., 2013; Ismail et al., 2012; Kho et al., 2017; Macabago, 2017), and research skills (Basilio et al., 2019). Others have focused on research competence (Manongsong et al., 2018; Gomez et al., 2013; Formeloza et al., 2013; Davidson et al., 2015; Udompong, et al., 2014), and research literacy (Udompong, et al., 2014). It was found that teacher-researchers are competent with conceptual skills, while they are moderately competent in computational and technical skills (De la Cruz, 2016). Abarquez et al., (2013) reported that the Tourism and Hospitality Management faculty was competent in the technical aspects of conducting research. Public Secondary and Elementary school teachers were moderately capable of writing a research proposal and publishable paper, while they are not skillful enough in conducting classroom-based research (Abarro et al., 2016). However, public teachers perceived a moderate level of difficulty in some aspect of action research, such as statistics, data organization, literature searching, and writing reports (Morales et al., 2016). Narag et al. (2016) revealed that Business Entrepreneurship and Accountancy faculty were very equipped in terms of knowledge and technical aspects of research capability. Master teachers have fair skills in designing the experimental study, selecting and developing research instruments, choosing appropriate statistical tools, and preparing manuscripts for publication (Basilio et al., 2019). Lastly, Macabago (2017) found public elementary teachers were in doubt with their capability to write research.

Previous correlational studies have found significant relationships among research time, teamwork, leadership support, training opportunities, and the research capability of nurses (Li et al., 2019); between the employment status and research capabilities of Business Entrepreneurship and Accountancy faculty (Narag et al., 2016); between attitudes toward research, in particular, its motivational factor and the research competence of Dentistry faculty (Manongsong et al., 2018), among the usefulness of research to the profession, research anxiety, positive attitudes toward research, research relevance to life, research difficulty, knowledge of research, mentoring, financial assistance, research facilities and resource materials, research incentives, and rewards with the research capability of Master Teachers (Wong, 2019), and research capabilities and motivation of public elementary teachers (Macabago, 2017).

In explanatory studies, the perception of Indonesian foreign teachers was influenced by their capability to conduct action and classroom research in which $7.45 \%$ variance of the former can be explained by the latter (Pati, 2014); the training attended related to research, attitudes toward research, and knowledge about research can predict the research capability of Mater Teachers in which $66 \%$ variance of their research capability can be explained by these combined independent variables (Wong, 2019). To date, this is the only available study that estimated variances of these variables on research capability. And so, there is a need to extend this trajectory of investigation.

The Department of Education (2015) began institutionalizing research through DO No. 13, s. 2015, which established a systematic development policy process and promoted an evidence-based policy formulation backed by research. Through DO No. 43, s. 2015 and DO No. 4, s. 2016, financial support to researchers was provided and the guidelines on the use of Basic Education Research Fund were set, respectively (DepEd, 2015, 2016). In the same year, another policy (DO No. 39, s. 2016) 
was issued that laid down the research agenda so that research of teachers would be aligned to priorities (DepEd, 2016). Lastly, an issuance was released (DO No. 16, s. 2017) to give guidance on the management of research affairs at all levels (DepEd, 2017). Thus, DepEd has been trying to push teachers to engage in research.

However, public school teachers need to develop and enhance the research capabilities that would enable them to produce research outputs. But they cannot do it by themselves and the agency and its partners shall work together to enable teachers to acquire and develop knowledge, skills, values, positive attitudes, which can add value to every researcher. It is then they can fully embrace the policies. On this premise, a study was carried out to assess the research capability of teachers and determine its correlates and determinants. It would also identify prospects for the professional development of teachers. For these, the results of this assessment can be made bases on the development of an intervention.

\section{Methodology}

Descriptive-correlational and predictive methods were employed by using researcher-made and adapted survey questionnaires administered to 92 teachers. These questionnaires included the 12 -item capability to conduct research, 9-item attitudes toward research, 14-item motivation to write research adapted from Macabago, (2017), 11-item on difficulty and non-difficulty in the research processes by Morales et al. (2016), 9-item on action planning skills, and the 5-item mentoring skills based on literature. Both the adapted and researcher-made questionnaires were subjected to content and face validation by the two experts and experienced professors and one Senior Education Program Specialist in Research and Planning at the division of Malaybalay City. The actual instrument has preliminary information on teachers' profiles. The data were gathered by observing the protocols or asking permission from authorities and by seeing consent from participants. Regarding research capability, participants had responses ranging from very capable (5) to not capable at all (1). On attitudes toward research and motivation to write, they had these choices ranging from strongly agree (5) to strongly disagree (1). For the different research processes, they chose from a very high level of difficulty (5) to no difficulty at all (1). All of these constitute the adapted survey questionnaires. The research-made questionnaire was subjected to content and face validity. This is on action planning and mentoring skills. For the former, participants responded between very capable of planning (5) to not capable at all (1), for the latter they chose from very true to me (5) to not true to me at all (1). The mean and the standard deviation were employed in drawing descriptive information. Pearson product-moment correlation was used in associating variables to determine the correlates of their research capability. Multiple regression and the stepwise method were utilized to determine the determinants of public teachers' research capability.

\section{Results and Discussion}

\subsection{Capability to Conduct Research}

As has been argued, research capability is essential in completing a research output. Teachers must have the facility to undertake high-quality inquiry (Salom, 2013). The overall response of the 92 participants showed that they were slightly capable of conducting research. These suggest that there is a need to enhance the capabilities of these teachers especially on the conceptualization and processes of action research including time management. Financial resources can be addressed if the training is provided unto them for free. They need to be provided with resources for writing like internet connections, books, journals, and samples of action research that may help them in the process. Also, teachers indicated a fair level of competence in conducting research (Alumbro et al., 2015), designing an experimental study, selecting and developing research instruments, choosing appropriate statistical tools, and preparing manuscripts for publication (Basilio et al., 2019).

Table 1. Capability of Teachers to Conduct Research

Indicators

Mean

SD

Qualitative

Description

1 My school head and my co-teachers support and encourage me to conduct action research.

2 My workload is not that constricted.

3 I have access to internet, books and sample action research.

4 Action research requires me little physical effort

5 We have a culture of action research in our school.

6 I have resource persons to refer to and will provide me professional assistance to conduct action research.

7 I have training/s with the concept and process of action research.

8 I have sufficient time [to conduct action research].

$\begin{array}{lll}3.82 & 1.02 & \text { Capable } \\ 3.08 & 1.20 & \text { Undecided } \\ 3.10 & 1.15 & \text { Undecided } \\ 2.89 & 1.24 & \text { Undecided } \\ 3.01 & 1.15 & \text { Undecided } \\ 2.75 & 1.31 & \text { Undecided } \\ & & \\ 2.28 & 1.13 & \text { Slightly Capable } \\ 2.20 & 1.09 & \text { Slightly Capable }\end{array}$


9 I have enough resources to finance this undertaking.

10 I can easily finish a study.

11 I have completed an action research.

12 I am conducting action research every year. Overall Mean

$\begin{array}{lll}2.08 & 1.00 & \text { Slightly Capable } \\ 1.97 & .90 & \text { Slightly Capable } \\ 1.63 & .93 & \text { Not capable } \\ 1.55 & .92 & \text { Not capable } \\ 2.53 & .79 & \text { Slightly Capable }\end{array}$

Conversely, empirical evidence revealed that teacher-researchers are competent with conceptual skills (De la Cruz, 2016), and on technical aspects of conducting research (Abarquez et al., 2013). On the positive side, faculty was very equipped with the knowledge and technical aspects of research capability (Narag et al., 2016), competent to conduct research (Tan, 2012), and has a high level of research capability (Enero et al., 2017) and high level of competence in different research tasks (Cuntapay et al., 2014). As expected, Dapiawen (2017) reported that graduate school faculty had an expert level of knowledge on the parts of research papers and had a high capability of accomplishing different research activities.

Indicators 2, 3, 4, 5, and 6, they were undecided, while indicators 6, 7, 8, 9, and 10 teachers were slightly capable. In one indicator, they admitted they were capable to conduct research. This is on support and encouragement from their school heads and co-teachers. To some extent, the results in these indicators support earlier findings that revealed public secondary and elementary school teachers were moderately capable (Cagaanan et al., 2018) in writing a research proposal and publishable paper (Abarro et al., 2016), and computational and technical skills (De la Cruz, 2016).

It can be gleaned that in two indicators teachers admitted they were not capable of conducting research. These are on being able to complete a study and conduct research every year. The results somehow affirmed previous findings that claimed teachers are not skillful in conducting classroom research (Abarro et al., 2016). More precisely, the results corroborate with the previous report that public elementary teachers were in doubt with their capability to write a research (Macabago, 2017).

\subsection{Attitudes toward Research}

Table 2 shows public school teachers' attitudes toward research. As can be seen, they agreed on the first three indicators. These are on the usefulness of action research to teaching, its benefits, and for considering it as indispensable in the profession. Positive attitudes are indicated for disagreeing that action research is stressful and difficult. However, they are undecided in another four indicators. These are on their interest and anxiety as well as on whether or not they love and enjoy doing action research. As a whole, they are undecided with their attitudes toward research. This may indicate neutrality or disinterest. Thus, they may have misconceptions about the value and importance of doing research. The results suggest that there is a need to provide teachers with training that informed them properly about research and can eventually enhance their attitudes toward research, and these misconceptions would be eradicated.

Table 2. Attitudes toward Research

\begin{tabular}{lllll}
\hline Indicators & Mean & SD & $\begin{array}{c}\text { Qualitative } \\
\text { Description }\end{array}$ \\
\hline 1 & Action research is useful for my teaching. & 3.85 & 1.18 & Agree \\
2 & I will benefit from conducting action research. & 3.82 & 1.15 & Agree \\
3 & Action research is indispensable in my professional training. & 3.70 & 1.07 & Agree \\
4 & To conduct action research is stressful. & 2.42 & 1.16 & Disagree \\
5 & Action research is difficult to conduct. & 2.46 & 1.09 & Disagree \\
6 & I have an interest to conducting action research. & 3.29 & 1.20 & Undecided \\
7 & Action research makes me anxious. & 2.73 & 1.09 & Undecided \\
8 & I love to conduct action research. & 2.82 & 1.16 & Undecided \\
9 & I enjoy [conducting an] action research. & 2.68 & 1.06 & Undecided \\
& Overall Mean & 3.08 & .69 & Undecided
\end{tabular}

On the contrary, Morales et al. (2016) indicated that teachers have positive views towards action research that can help them develop student learning and promote lifelong learning. Younger teachers demonstrate more sensitivity towards educational research than those who have been teaching five years and above (Akcoltekin et al., 2017), and teaching personnel has highly developed and sustainable attitudes toward research (Pamatmat, 2016). The teacher-respondents had a positive attitude toward doing research and its benefits in their teaching (Ulla et al., 2017). Kho et al. (2017) made known that lecturers can 
distinguish different parts of action research and were able to cite the authors appropriately. Pati (2014) disclosed that teachers had a high perception in researching terms of image, but in terms of time, cost, technicality, and efforts, their attitudes-based perception got low. Basilio et al. (2019) also revealed that master teachers have high regard for the value of researching to become better educators. As claimed further, efforts, time, and resources in learning research findings are essential elements in developing positive attitudes toward research.

\subsection{Motivation to Write Research}

Table 3 presents the motivation of public-school teachers. In general, they agreed on most indicators of motivation to write research. These are on what research can do to their promotion, teaching efficiency, socialization, outranking other applicants in the promotion, commitment towards it, publication productivity, passion to discover for new knowledge, and their empowerment. These indicators are composed of internal and external dimensions. For these reasons, they agreed that they were motivated to write research. However, they indicated undecided in four indicators that most of their co-teachers have conducted or have plans to conduct research, on participation and recognition during research congress, the financial benefit of the research, and to show unto co-teachers that research is not difficult. This means that many teachers do not have an interest in conducting research. Although their overall motivation seems to be positive, yet they still need training in this aspect to enhance their motivation to write research.

Table 3. Motivation to Write Research

\begin{tabular}{|c|c|c|c|c|}
\hline \multicolumn{2}{|c|}{ Indicators } & \multirow{2}{*}{\begin{tabular}{|l} 
Mean \\
4.11
\end{tabular}} & \multirow{2}{*}{$\begin{array}{l}\text { SD } \\
.82\end{array}$} & \multirow{2}{*}{$\begin{array}{l}\text { Qualitative } \\
\text { Description }\end{array}$} \\
\hline 1. & Action research enhances my chance for career promotion. & & & \\
\hline 2. & Action research enhances my teaching efficiency. & 3.87 & .98 & Agree \\
\hline 3. & My school head expects me to come up with action research by the end of the year & 3.82 & .96 & Agree \\
\hline 4. & I would like to interact with other teacher-researchers. & 3.89 & .87 & Agree \\
\hline 5. & [Conducting] action research allows me to outrank other applicants [for promotion]. & 2.42 & 1.01 & Agree \\
\hline 6. & Most of my co-teachers have conducted or planned to conductaction research. & 3.23 & .99 & Undecided \\
\hline 7. & My school head will recognize my commitment to [do] action research. & 3.77 & .92 & Agree \\
\hline 8. & I would like to publish action research findings to research journals. & 3.60 & 1.10 & Agree \\
\hline 9. & I find action research as an interesting and meaningful educational practice. & 3.58 & 1.05 & Agree \\
\hline 10. & I would like to participate and be recognized in the research congress. & 3.39 & 1.06 & Undecided \\
\hline 11. & Action research allows me to come out financially ahead. & 3.27 & .97 & Undecided \\
\hline 12. & $\begin{array}{l}\text { I would like to demonstrate to my peers that the conduct of action research is not } \\
\text { that difficult. }\end{array}$ & 3.12 & .95 & Undecided \\
\hline 13. & I have a passion for the discovery of new knowledge. & 3.73 & .91 & Agree \\
\hline \multirow[t]{2}{*}{14.} & I feel empowered when I investigate and take actions to classroom problems. & 3.55 & .95 & Agree \\
\hline & Overall Mean & 3.61 & .69 & Agree \\
\hline
\end{tabular}

In Akcoltekin et al. (2017), female teachers showed greater interest in educational research than their counterparts. The faculty were highly motivated in terms of fringe benefits and opportunities to grow professionally (Tan, 2012). This literature was supported by this assertion that faculty showed fair and positive interest toward research, and this interest becomes low when researching without funds or research assistance (Alumbro et al., 2015). In a university setting, the utilization of research, personal satisfaction, expanding network, research capability program, and support of the administration were the top five factors of teachers' motivation to conduct research (Narbarte et al., 2018). College of Arts and Sciences faculty were found motivated by the research capability building seminars and workshops (Cuntapay et al., 2014).

\subsection{Difficulty and Non-Difficulty in Research Processes}

Table 4 presents the difficulty and non-difficulties of public-school teachers in different research processes. Explicitly, these teachers perceived a high level of difficulty in research processes. The top four most difficult processes are analyzing qualitative data, followed by organizing and writing the findings, analyzing quantitative data, and making a relevant presentation and writing an article for publication. The results indicate that there is a need for training that can enhance teachers' skills in these processes in writing research. These processes should be the focus and emphasis on continuing professional development activities. The present results are somehow true in the findings of mixed-method research by Morales et al. (2016), who 
reported that public teachers perceived a moderate level of difficulty on certain aspects of action research. The difficulties of the participants in different research processes need more attention and immediate actions. This is due to the limited opportunities for training in the locale. A study was confirmed for its claim that graduate students have much difficulty in conceptualizing research problems and titles, looking for and reviewing related literature and studies, determining appropriate statistical tools, gathering the data, and analyzing and interpreting the data (Ocbian et al., 2015). A more recent study revealed that junior high school teachers have difficulties in conducting action research, particularly in literature search, presentation of results, the publication of results, and data collection (Tindowen et al., 2019).

Table 4. Difficulty and Non-Difficulty in Research Processes

\begin{tabular}{|c|c|c|c|c|}
\hline \multicolumn{2}{|c|}{ Indicators } & Mean & SD & $\begin{array}{l}\text { Qualitative } \\
\text { Description }\end{array}$ \\
\hline 1. & Identifying issues and problems to be investigated byaction research. & 3.47 & .95 & High level of difficulty \\
\hline 2. & Searching for relevant literature on my chosen topic for research. & 3.48 & .93 & High level of difficulty \\
\hline 3. & $\begin{array}{l}\text { Developing the processes of how to do research and collective evidence } \\
\text { of research. }\end{array}$ & 3.58 & .92 & High level of difficulty \\
\hline 4. & Analyzing quantitative data. & 3.62 & .92 & High level of difficulty \\
\hline 5. & Analyzing qualitative data. & 3.64 & .96 & High level of difficulty \\
\hline 6. & Organizing and writing the findings & 3.63 & 1.00 & High level of difficulty \\
\hline 7. & Making a relevant presentation on my project and write an article for publication. & 3.62 & .97 & High level of difficulty \\
\hline 8. & Using technology in literature search. & 3.42 & 1.04 & High level of difficulty \\
\hline 9. & Using technology in data presentation. & 3.45 & 1.08 & High level of difficulty \\
\hline 10. & Using technology in statistical analysis. & 3.59 & 1.03 & High level of difficulty \\
\hline 11. & Using technology in bibliographical entries. & 3.44 & 1.09 & High level of difficulty \\
\hline & Overall Mean & 3.41 & .40 & High level of difficulty \\
\hline
\end{tabular}

\subsection{Action Planning Skills}

The action planning skills of the public-school teachers are shown in Table 5. It can be noticed that they find themselves moderately cable of action planning across all indicators. These results indicate somehow the need to improve teachers' actionplanning skills. This is so because the said skill is vital in making action research wherein an action plan is one of the vital components of this type of research. No literature supports these results.

Table 5. Action Planning Skills

Indicators

$\begin{array}{ll}\text { Mean SD } & \begin{array}{l}\text { Qualitative } \\ \text { Description }\end{array}\end{array}$

1. Set the overall goal of the intervention plan based on the identified classroom needs/issues/problems/gaps.

2. Formulate clear, specific, measurable, doable and aligned objectives to the goal.

3. Create strategies and schedule activities that would achieve the goals and objectives using a Gantt chart.

4. Identify the materials and resources to use.

5. Prepare the monitoring tools.

6. Monitor the activities using the data gathering tools and methods.

7. Evaluate the intervention plan based on the gathered information in the implementation and monitoring.

8. Extract new information from the gathered data.

9. Examine/reflect whether or not the intervention plan improves the practice of your profession.

Overall Mean

$\begin{array}{lll}3.29 & .89 & \text { Moderately capable } \\ 3.21 & .94 & \begin{array}{l}\text { Moderately capable } \\ \text { Moderately capable }\end{array} \\ 3.25 & 1.00 & \text { Moderately capable } \\ 3.19 & .97 & \text { Moderately capable } \\ 3.03 & 1.04 & \text { Moderately capable } \\ 2.98 & 1.01 & \text { Moderately capable } \\ 2.97 & 1.06 & \\ & & \text { Moderately capable } \\ 3.09 & 1.05 & \text { Moderately capable } \\ 3.05 & 1.04 & \\ 2.74 & .27 & \text { Moderately capable }\end{array}$




\subsection{Mentoring Skills}

Table 6 shows the mentoring skills of public-school teachers. As can be seen, they responded somewhat true to me in all indicators. This simply means that they have the potential to mentor others to conduct research. These skills are developing in them. However, these skills still need improvement by providing them with relevant capacity-building programs and activities. The study by Tan (2011) discovered that mentoring requires synchronization of the steps to complete the study of the mentee, symbiotic nurturing and learning, and synergetic celebration of the outputs and outcomes of their collaboration. Its success lies in proper time management, quality attributes and attitudes of both mentors and mentees, and the appropriate manner of undertaking research. On the other hand, Mohan (2010) found out instances of misunderstanding between the mentor and mentee, and most of the mentees were not inclined to do collaborative research, and some mentees dropped out. Besides, Soriano (2018) made know that advisers or mentees were evaluated by advisees or mentees as skilled in terms of intellectual growth and development, research conduct, professional career and development, academic guidance, skills development, and personal communication, while they were highly skilled in research ethics.

Table 6. Mentoring Skills

\begin{tabular}{llll}
\hline Indicators & Mean & SD & $\begin{array}{c}\text { Qualitative } \\
\text { Description }\end{array}$ \\
\hline 1. I like to take the lead in improving our productivity in research. & 3.21 & .92 & Somewhat true to me \\
2. I like other teachers to learn from my experience, training and knowledge & 3.17 & 1.04 & Somewhat true to me \\
of research. & & & \\
3. I have the passion to teach, mentor, and guide others to complete a study. & 3.16 & 1.10 & Somewhat true to me \\
4. I want to help the school and our school head to produce a study every year. & 3.29 & .96 & Somewhat true to me \\
5. I am willing to help other teachers acquire the research skills, knowledge, & 3.23 & .99 & Somewhat true to me \\
$\quad$, and development of the positive attitudes toward inquiry and innovation. & & & Somewhat true to me
\end{tabular}

\subsection{Correlates of Research Capability}

Table 7 presents the results of associating the research capability of public-school teachers to their attitudes toward research, motivation to write research, difficulty, and non-difficulty in different research processes, mentoring and action planning skills, age, years of service, and the number of studies completed. As revealed, the research capability of teachers has a moderate, positive, and significant relationship with their mentoring skills $(r=.542, p<0.05)$ and motivation to write research $(r=.569$, $\mathrm{p}<0.05)$, respectively. Wong (2019) reported a significant relationship between research mentoring and the research capability of master teachers. The present study affirms Macabago (2017) whose study found a positive and significant relationship between elementary teachers' research capabilities and motivation to write research.

Table 7. Correlates of Research Capability

\begin{tabular}{llcl}
\hline Variables & & Research Capability & Remarks \\
& & coefficient & significant \\
Mentoring skills & $.542^{* *}$ & .000 & significant \\
Action planning skills & $.291^{* *}$ & .005 & not significant \\
Difficulty/non-difficulty in Research Processes & .130 & .297 & significant \\
Attitudes toward Research & $.473^{* *}$ & .000 & significant \\
Motivation to Write Research & $.569^{* *}$ & .000 & significant \\
Age & $-.383^{* *}$ & .001 & significant \\
Years of Service & $-.377^{* *}$ & .001 & significant
\end{tabular}

Notes: $\quad * *$. Correlation is significant at the 0.01 level (2-tailed). Coefficients: .90 to 1.00 (-.90 to -1.00) Very high positive (negative) correlation; .70 to .90 (-.70 to -.90) High positive (negative) correlation; .50 to .70 (-.50 to -.70) Moderate positive (negative) correlation; .30 to .50 (-.30 to -.50$)$ Low positive (negative) correlation; and .00 to .30 (.00 to -.30$)$ negligible correlation

There was a low, positive, and significant relationship with attitudes toward research $(r=.473, p<0.05)$ and the number of studies completed $(r=.350, p<0.05)$, singly. The results confirm the previous findings that there was a positive and significant 
relationship between the research competence of the faculty and their attitudes (motivation) toward research (Manongsong et al., 2018; Wong, 2019). Moreover, there was a low, negative, and significant relationship between age $(r=-.383, p<0.05)$ and the years of service $(r=-.377, p<0.05)$. Lastly, a negligible, positive and significant relationship occurred between their research capability and the action planning skills $(r=.291, p<0.05)$. The results further show that there was no significant relationship between the teachers' research capability and the difficulty or non-difficulty of the research processes. This is contradictory to the research findings of the previous study (Wong, 2019).

\subsection{Determinants of Research Capability}

Tables 8 and 9 display the ANOVA and regression analysis results of the three models. F stat (model 1$)=23.777, p<.05$ revealed that the first model of research capability is statistically significant. Using the stepwise method of regression, this model identified one determinant variable, the motivation of teachers to write research. The regression analysis further revealed that the motivation to write can explain variance in the outcome variable at 28 percent. This means that for every unit of increase in research capability of public-school teachers, this is the variance that can be attributed to teachers' motivation to write research. Nevertheless, research capability does not have a significant beta weight as a constant in the regression equation. This analysis yielded the equation model of $Y$ (research capability) $=.051+.692$ (motivation to write research) +.65335 (standard error).

Table 8. ANOVA Results

\begin{tabular}{|c|c|c|c|c|c|c|}
\hline Models & Sources & Sum of Square & $\mathrm{df}$ & Mean Square & $\mathrm{F}$ & sig. \\
\hline \multirow[t]{3}{*}{1} & Regression & 10.150 & 1 & 10.150 & 23.777 & .000 \\
\hline & Residual & 26.039 & 61 & .427 & & \\
\hline & Total & 36.189 & 62 & & & \\
\hline \multirow[t]{3}{*}{2} & Regression & 14.091 & 2 & 7.045 & 19.129 & .000 \\
\hline & Residual & 22.098 & 60 & .368 & & \\
\hline & Total & 36.189 & 62 & & & \\
\hline \multirow[t]{3}{*}{3} & Regression & 15.713 & 3 & 5.238 & 15.092 & .000 \\
\hline & Residual & 20.476 & 59 & .347 & & \\
\hline & Total & 36.189 & 62 & & & \\
\hline
\end{tabular}

F stat $(2)=19.129, p<.05$ unveiled that the second model of research capability is also statistically significant. This model has two determinant variables: the motivation to write research, and the number of studies completed by teachers. Both were found statistically significant determinants of research capability. When combined, they can explain a $38.9 \%$ variance in the outcome variable. This would suggest that for every unit increase in the research capability of teachers, this is the portion that can be ascribed to teachers' motivation and the number of studies completed. Moreover, the number of completed studies is concrete evidence that teachers possess the capability. This regression analysis generated the equation model of $Y$ (Research capability) $=.335+.594$ (Motivation to write research) +.526 (Number of studies completed) +.60688 (Standard Error).

The third model of research capability was found to be statistically significant $(F=15.092,3, p<.05)$. This model has three determinant variables: motivation to write research, the number of studies completed, and the age of the teachers. This model has the highest determination coefficient of 43.4 percent. This implies that these three determinant variables can explain $43.4 \%$ variance in teachers' research capability. However, age can negatively impact teachers' research capability, as evidenced by the beta coefficient. This can be explained in two ways. One, the result would indicate that as the teachers get older, the less likely they become capable to write research. This is the case since many participants aged 35 and above were graduates from the old curriculum which did not offer research subjects in their program in college. Second, this result may be true as the teachers increase their age, the less capable they become because research has a rigor that demands more time, energy, and effort. Therefore, it is an advantage when teachers engage in research when they are still young. It goes to say that older teachers are of a disadvantage when it comes to research capability. Thus, it is wise to invest so much for capability building among the younger teachers. This analysis produced the equation model of $Y$ (Research capability) $=1.473+.475$ (Motivation to write research) +.575 (Number of studies completed) -.018 (Age) +.58911 (Standard Error). Comparing the three models, research capability as a function of motivation to write research, age, and the number of studies completed is more robust. 
Table 9. Determinants of Research Capability

\begin{tabular}{|c|c|c|c|c|}
\hline Models & Variables & $\begin{array}{l}\text { Unstandardized } \\
\text { Coefficient }\end{array}$ & $\begin{array}{l}\text { Standard } \\
\text { Error }\end{array}$ & Sig. \\
\hline \multirow[t]{2}{*}{1} & Research Capability & .052 & .516 & .920 \\
\hline & Motivation to Write Research & .692 & .142 & .000 \\
\hline \multirow[t]{3}{*}{2} & Research Capability & .335 & .487 & .495 \\
\hline & Motivation to Write Research & .594 & .135 & .000 \\
\hline & Number of Studies Completed & .526 & .161 & .002 \\
\hline \multirow[t]{4}{*}{3} & Research Capability & 1.473 & .708 & .042 \\
\hline & Motivation to Write Research & .475 & .142 & .001 \\
\hline & Number of Studies completed & .575 & .158 & .001 \\
\hline & Age & -.018 & .008 & .035 \\
\hline
\end{tabular}

Notes: $\quad$ Model 1: $\mathrm{R}=.530, \mathrm{R}^{2}=.280(28 \%)$; Model 2: $\mathrm{R}=.624 \mathrm{R}^{2}=.389(38.9 \%)$; Mode 3: $\mathrm{R}=.659, \mathrm{R}^{2}=.434(43.4 \%)$

Wong's (2019) findings revealed that the research capability of teachers can be explained by training attended related to research, attitudes toward research, and the knowledge about research at 66 percent variance. The knowledge about research can largely explain the research capability (.58), followed by attitudes toward research (.20), and by training attended (.10). Whereas, Pati (2014) revealed that Indonesian foreign teachers' perceptions of research were influenced by their capability to conduct action and classroom research. This means that an increase, improvement, or changes in their perception toward research, 7.455 of which can be accounted for their capability to conduct action research. In this case, research capability was an independent variable. A cross-sectional study also reported that the research capability of nurses was influenced by research time, teamwork, leadership support, and retraining opportunities (Li et al., 2019). Besides, the research capability of the faculty was influenced by teachers' motivation to conduct research (Tan, 2012). Years ago, regression analysis found that research capability was influenced by attitudes and personal interest in research, educational attainment, leadership skills in research (admin), research facilities, length of service, and research training (Fetalver, 2010). However, the determination coefficient was not reported and the nature of the influence of each variable or in combination, whether it was a negative or positive effect.

\section{Conclusion}

The number of studies completed, the motivation to write research, and age determined the public-school teachers' research capability. Thus, it is important to note that the best indicator and the most concrete manifestation that teachers are capable of doing research is the research output itself or sometimes called research productivity. This means that the more studies teachers have completed, the more capable they become in engaging in this rigorous endeavor. Also, age is detrimental to teachers' research capability. It is better to expose teachers in research when they are still very young and prioritize them for continuing professional development. Moreover, it is vital also to enhance teachers' their motivation to write a research. Based on the descriptive results, it was concluded that public school teachers have training needs in all areas covered in the assessment. However, the Continuing Professional Development through Extension Services of the Bukidnon State University may emphasize the different processes of research, attitudes toward research, the motivation to write research, and most especially on the capability to conduct research. The in-charge or coordinators of research programs in public schools or at the division level need to consider these areas so that they can ensure increased productivity and their programs are cost-effective. The intervention project they would design and implement must target the key points articulated in this paper.

\section{Acknowledgement}

Special thanks are due to the officials, school administrators, and teachers of the Malaybalay City Division for the support and constant partnership. The same gratitude is due to the officials of the extension unit, Bukidnon State University, for their leadership and guidance. 


\section{References}

[1] Abarquez, R. R. \& Palbaca, J. A. (2013). Research Capabilities of International Tourism and Hospitality Management Faculty Members. Journal of Tourism and Hospitality Research, 10(1), 46-55. https://bit.ly/2UNyUP2

[2] Abarro, J. O. \& Mariño, W. P. (2016). Research Capabilities of Public Secondary and Elementary School Teachers in the Division of Antipolo City. International Journal of Scientific and Research Publications, 6(6), 407-410. https://bit.ly/3bF9DNJ

[3] Akcoltekin, A., Engin, A. O. \& Sevgin, H. (2017). Attitudes of High School Teachers to Education Research using Classification Tree Method. Eurasian Journal of Education Research, 68, 19-47. https://bit.ly/3bC1Z6T

[4] Alhija, F. M. N. \& Majdob, A. (2017). Predictors of Teacher Educators' Research Productivity. Australian Journal of Teacher Education, 42 (11), 34-51. Retrieved from http://bit.ly/2LZ1RVk

[5] Alumbro, E. C., Cuadra, L. J., \& Sapan, M. J. M. (2015). Recognizing Research Competence and Interest as Basis for Faculty Development Initiatives. JPAIR Institutional Research Journal, 5(1), 21-32. https://bit.ly/2yvYoJb

[6] Basilio, M. B., \& Bueno, D. C. (2019). Research Skills and Attitudes of Master Teachers in a Division Towards Capability Training. 19th CEBU Philippine International Conference on Economics, Education, Humanities and Social Sciences.

[7] Cagaanan, J. C. A., \& Gosadan, B. D. (2018). Research Competency among Elementary School Teachers: An evaluative assessment for School-Based Action Research (SBAR). JPAIR Institutional Research Journal, 11(1), https://bit.ly/2V5soDo

[8] Cuntapay, M. C., Garay, G., \& \&Viloria, P. F. (2014). Needs Assessment of Teacher's Research Capability. College of Arts and Sciences Research Journal, 5(1), https://bit.ly/2yyMQoB

[9] De la Cruz, J. L. (2016). The Research Capability of Ilocos Sur Polytechnic State College: A Basis for A Capability Enhancement Program. International Journal of Management and Social Sciences Research, 5(7), 39-45. https://bit.ly/2yAEnkU

[10] Dapiawen, A. A. (2017). Correlates of level of knowledge and research capability of the Graduate School faculty. UB Research Journal, XLI(2). https://bit.ly/2XmSa9a

[11] Davidson, Z. E., \& Palermo, C. (2015). Developing Research Competence in Undergraduate Students through Hands on Learning. Journal of Biomedical Education, 1-9. https://bit.ly/2UwomEY

[12] Department of Education. (2015). DepEd order No. 13, s. 2015: Establishment of a Policy Development Process at the Department of Education. DepEd. https://bit.ly/2y5nPB4

[13] Department of Education. (2016). DepEd Order No. 39, s. 2016: Adoption of Basic Education Research Agenda. DepEd. https://bit.ly/2RHoG2b

[14] Department of Education. (2017). DepEd Order No. 16, s. 2017: Research Management Guidelines. DepEd. https://bit.ly/3aWfoH6

[15] Department of Education. (2015). DepEd Order No. 43, s. 2015: Revised Guidelines for the Basic Research Fund. DepEd. https://bit.ly/39WuBXo

[16] Department of Education. (2016). DepEd Order No. 4, s. 2016: Amendment to DepEd No. 43, s. 2015: Revised Guidelines for the Basic Research Fund. DepEd. https://bit.ly/3eeBo22

[17] Enero, A. J. P. \& Limjuco, R. P. (2017). Determinants of Research Publication Productivity among Faculty of Education Institutions in Region XI: Basis for Institutional Research Program Enhancement. International Journal of Education Research for Higher Learning, 23(2), 21-53.

[18] Fetalver, M. A. (2010). Selected Predictors of Research Capability in Terms of Research Management and Research Process in State Higher Education Institutions in Region IV. Research Journal College of Engineering, 3(1). https://bit.ly/39yzs0G

[19] Formeloza, R., \& Pateña, A. D. (2013). Research Capability of the Maritime Faculty Members and Senior Students in Lyceum International Maritime Academy. International Journal of Physical and Social Sciences, 3(9), 275-288. https://bit.ly/2wFDCXf

[20] Gomez, M. J. S., \& Panaligan, C. (2013). Level of Research Competencies and Satisfaction of the Faculty Members from the College of Criminology. Asian Academic Journal of Social Sciences and Humanities (14), 269-280. https://bit.ly/3bDy91V

[21] Holt, J., \& Perry, S. A. (2011). Ä Pragmatic guide to Competency: Tools, Frameworks and Assessments. British Informatics Society Ltd. https://bit.ly/34aElvS

[22] Ismail, R., \& Meerah, S. M. T. (2012). Evaluating the Research Competencies of Doctoral Students. Procedia - Social and Behavioral Sciences, 59, $244-247$. https://bit.ly/341RYNV

[23] Kho, M. G.W. \& Ling, Y. L. (2017). A Study of Perception and Capability to Undertake Action Research Among Lecturers at a Polytechnic in Sarawak. Teacher Education and Curriculum Studies, 2 (4), 41-46. Retrieved from http://bit.ly/2099ivV

[24] Li, X. D., Chen, H. J., Wang, L., Kong, X. Y., \& Ying, J. (2019). Scientific Research Capability and Continuing Education Needs for Nurses with Master's Degree in China. The Journal of Continuing Education in Nursing, 50(2), 61-68.

[25] Macabago, S. M. (2017). Teachers' Motivation, Attitude, Perceived Capability, and Difficulty to Conduct Action Research: A Basis for Intervention Plan for Public Elementary School Teachers (unpublished thesis). Malaybalay City, Bukidnon: Bukidnon State University.

[26] Mani, M. C., Fetalvero, E. G., Foja, L. G., \& Formento, A, F. (2010). Research Capability Building-A Strategy to Promote Research Culture in SUCs and Countryside Development: The Romblom State College Experience. PHILARM Journal, 7(1), $147-165$. https://bit.ly/2WVDA8g

[27] Manongsong, M. J. G. \& Panopio, E. (2018). Dentistry Faculty Members' Research Competencies and Attitude towards Research Engagement. Asia Pacific Journal of Education, Arts and Sciences, 5(3), 13-19. https://bit.ly/3dlaAXn

[28] Mohan, V. V. (2010). Mentoring Doctoral Students in a Developing Society. Issues in Informing Science and Information Technology, 7, 249-264. https://bit.ly/2w2yY55 
[29] Morales, M. P. E., Abulon, E. L. R., Soriano, P. R., David, A. P., Hermosisima, M. V. C. \& Gerundio, M. G. (2016). Examining teachers' conception of and needs on action research. Issues in Educational Research, 26(3), 464-489. https://bit.ly/2UQWsm3

[30] Narag, E. R., Gannaban, M. V. C. \& Agustin, C. (2016). Research Capabilities of the Faculty Members of CBEA of Cagayan State University, Andrews Campus. International Journal of Advanced Research in Management and Social Sciences, 5(2), 10-16. https://bit.ly/343ZlnO

[31] Narbarte, M. P., \& Balila, J. S. (2018). Research Involvement, Motivation, and University Initiatives as Agents for Enhancing Research Culture and Quality. Catalyst, 17, 68-78. https://bit.ly/2x7sRx8

[32] Ocbian, M. M., \& Gamba, M. P. (2015). SSC Graduate Students' Difficulties in Doing Research. JPAIR Institutional Research Journal, 5(1), 49-64. https://bit.ly/2xV6Ml9

[33] Pamatmat, F. V. (2016). Research Attitudes of Teaching Personnel in one Philippine State University: Basis for Development and Sustainability towards Excellence. Research Journal of Language, Literature and Humanities, 3(3), 12-17. https://bit.ly/3bKIYiF

[34] Pati, P. (2014). Indonesian Foreign School Teachers' Perception and Capability to Undertake Classroom Action Research: Basis for Capability Building Program. IOSR Journal of Research and Method in Education, 4(1), 67-89. https://bit.ly/2ykUble

[35] Salem, M. A., Shawtari, F., Shamsudin, M. F., Hussain, H. B. I. \& Hizam, S. M. (2016). Research Capability, Job Satisfaction, and a Multiple Approach of Competitiveness: A Conceptual Framework for University Kuala Lumpur, Malaysia. Retrieved from http://bit.ly/2JXHp4L

[36] Salom, M. D. (2013). Research Capability of the Faculty Members of DMMMSU MID Campus. E-International Scientific Research Journal, 5(2), 45-55.

[37] Soriano, H. A. S. (2018). Examining Thesis Advisers' Profile and their Undergraduate Research Mentoring Capabilities. Asia Pacific Journal of Education, Arts and Sciences, 5(3), 1-12. https://bit.ly/3byZClk

[38] Tan, E. (2011). "It takes two to tango:" The language of research mentoring. The Asian Journal of Educational Research and Synergy, 3(1). https://bit.ly/2UIBruX

[39] Tan, R. (2012). Motivation and Research Capability of the University of Cebu Faculty. International Journal of Nursing Practice, 8. ProQuest.

[40] Tindowen, D. J., Guzman, J., \& Macanang, D. (2019). Teachers' Conception and Difficulties in Doing Action Research. Universal Journal of Educational Research, 7(8), 1787-1794. https://bit.ly/2RoDen3

[41] Udompong, L., Traiwichitkhun, D., \& Wongwanich, S. (2014). Causal Model of Research Competency via Scientific Literacy of Teacher and Student. Procedia - Social and Behavioral Sciences, 116, 1581 - 1586. https://bit.ly/2WYNHZP

[42] Ulla, M. B., Barrera, K. B., \& Acompanado, M. M. (2017). Philippine Classroom Teachers as Researchers: Teachers' Perceptions, Motivations, and Challenges. Australian Journal of Teacher Education, 42(11). http://ro.ecu.edu.au/ajte/vol

[43] Wong, A. M. (2019). Driving Forces of Master Teachers' Research Capability: Towards Building a Research Culture in the Division of Romblon, Philippines. International Journal of Advanced Research and Publications, 3(7), 92-97. https://bit.ly/39tzE13 